\title{
COMMUNITY SERVICE IMPOSED UPON THE CONVICTED CORRUPTOR IN ACTUALIZING LOCAL WISDOM AS CULTURAL HERITAGE
}

\author{
Dewi Asri Yustia ${ }^{1}$, Gialdah Tapiansari Batubara ${ }^{2}$, Tia Ludiana ${ }^{3}$ \\ ${ }^{1,2,3}$ Law Faculty, Universitas Pasundan, Bandung, West Java, Indonesia \\ 1dewi.asri@unpas.ac.id \\ ${ }^{2}$ gialdah.tapiansari@unpas.ac.id, \\ ${ }^{3}$ tia.ludiana@unpas.ac.id
}

\begin{abstract}
The optimalization of community service imposed upon the convicted corruptors is an effort to give a positif impact for the community in addition to reduce the burden of the state such as expenses for the intervention programs for the inmates and the correctional burden considering the the inmates possessed a more specific compentence either in knowledge, power and other fields compare to the competency held by the wardens, not to undermine them, and the security to maintain by the state. With the imposement of community service, the duty to enforce the sanction is transferred to the inmates not to the state and the benefit is not only for the state but also for the community since the competency held by the convict can be beneficial therefore it can be legal action to actualize the local wisdom regarding that the sanction imposed is more concentrated on the community's need and the community-based intervention program. Prison will no longer serves as the sole service providing correctional program for the corruptor. This is expected that with the recommendation for the reformation of the Penal Code and Anti-Corruption Act, the deterrence of the offenders as the objectives of sentencing can be accomplished. It is also expected that it can give a positif advantage for the community in addition to reduce the state burden through community service sanction to actualize the local wisdom as the cultural heritage.
\end{abstract}

Keyword : Inmates Intervention Program, Corruption, Community service sanction 


\section{Introduction}

Nowadays, laws related to the crime of corruption has been completed and is getting perfection in the matters of the offenses, the subject of the offense, and also the sanctions to be imposed upon. Looking back, the crime of corruption has been through a great change starting from the type of delict, the qualification of the act, and the criminal sanction imposed even though the category above is still debatable especially when it comes to the application of Article 2 and 3 of Law No. 20, 2001 concerning the Amendment of Law No. 31, 1997 concerning Crime of Corruption.

With the amendment, the development, in fact, is that the crime of corruption in Indonesia is reducing, however, it was done in more various modus and ways: from conventional to a more complicated; done by the executives, legislatives, business actors, including the judicatives and also the law enforcement (attorney and police).

It is obvious that criminal sanction imposed upon gives no any deterrence effect to neither the offender nor to the offender to be (community). In fact, if we consider the objectives of the punishment, the criminal sanction is actually expected to be the repressive measures for the offender and also preventive measures for the offender to be (community). However, if we take a look at the cases handled by the Corruption Eradication Commission (KPK) or those that had been adjudicated by judge, it is clear that criminal sanction imposed did not give any effect whatsoever to either the offender or to the offender to be, community, including to the country. Based on the data compiled by ICW in 2018 , the state loss as the result of corruption has reached 9, 2900 billion rupiahs accumulated from 926 defendants at District Court level, 208 cases at High Court level and 28 cases at Supreme Court level. While in 2019, KPK revealed potential state loss could be reached 200,000 billion rupiahs, the asset recovery done in 2018 was predicted only $8.7 \%$ of the total state loss through the punitive damage for as of 805,04 billion rupiahs.

During 2019, corruption mostly occurred in central government. It was recorded in the
Statistic of Area-based Corruption released by KPK. In 2019, cases mostly handled by KPK were bribery with total of 97 (ninety-seven) cases. Official position mostly involved in corruption were Mayor/Regent and the Deputies with 14 (fourteen) cases, Echelon I/II/III Civil Apparatus with 14 (fourteen cases), Members of Parliament (House of Representatives and Regional House of Representatives) of 10 cases. Government institutions with highest number of cases were Municipality and Regency Administration Office of 51(fifty-one) cases, Ministry/State Organ of 42 (fourty two) and State/Provinceowned enterprises of 42 (fourty two) cases.

Similar data released by Indonesian Corruption Watch points out that along 2020, some 1,218 cases of corruption has been tried at the Court for Corruption Case, High Court, and the Supreme Court. The total defendants adjudicated with corruption case were 1,298. From the data, it was recorded that the highest number of corruptions was committed by State Civil Apparatus with 321 cases followed with private sectors with 286 cases and village administration with 330 cases. ICW monitored the court trial for the corruption cases within period of January 2020 until December 2020. The findings showed that the total state loss was 56,700 billion rupiahs. This was four times higher than the loss in previous year. In 2019, referring to ICW data, the loss was 12,000 billion rupiahs. ICW also pointed out that the General Attorney handled more cases on state loss compared to what was handled by KPK. General Attorney handled the cases with total loss of 56,700 billion rupiahs while KPK handled cases with total loss of 114,8 billion rupiahs.

In 2021, some sources have been trying to estimate the potential state loss indicating the involvement of corruption. For example, the potential loss as the result of fictious civil servants was 151,39 billion rupiahs per month. This calculation was from the salary of the Civil Apparatus Level 1/a with working period under one year of 1,560,800 rupiahs times 97,000 fictious Civil Apparatus. BPK has calculated the state loss in 2021. The Audit Board of Indonesia (BPK) found that the potential state 
loss is of 2,94 trillion from 2,843 cases occurred in the Management of Covid-19 virus and the Restoration of National Economy in Semester II-2020. BPK found that the cases included 887 of the weak internal control system, 715 incompliance to the regulations with potential loss of 2,73 trillion rupiahs and 1,241 of $3 \mathrm{e}$ problems (excessiveness, inefficiency, ineffectiveness) with potential loss of 209,8 billion rupiahs. During the audit process of entity, BPK has been following up the incompliance by handing over the asset or submitting to the national deposit for about 18,54 billion rupiahs. With such condition, BPK concluded that effectiveness, transparency, accountability and management compliance and responsibility of the state finance in contingency of the Covid-19 virus outbreak was not fully accomplished.

Indonesia Corruption Watch (ICW) pointed out that the alleged potential loss was 169,1 billion rupiahs from the procurement of Covid-19 virus test kits i.e., reagen. ICW suggested or demanded KPK to take action against the findings of alleged corruption act in the procurement of the test kits during the handling of the Covid-19 virus outbreak. According to ICW, during April to September 2020, ICW has found that there was retours of reagen in about 78 labs in 29 provinces. The total of retour was 498, 644 test kits with value of 169,1 billion rupiahs. In data revealed by ICW, about 493,819 RNA reagen were retoured by the labs with total potential loss of 167,8 billion rupiahs while for PCR reagen retoured was 4,825 withpotential loss for about 1,5 billion rupiahs. Regardless the discrepancy in data from KPK and ICW, if we view the objectives of the sentencing, one of which is to give a deterrence effect to the offender, in addition to give lesson for the community (offender to be) and to recover the loss of state financial. However, if we compare the sanction imposed to the loss the state had to bear and the recovery of the state financial through punitive damage, it is not significant. From the above data and the data on sanction averagedly imposed upon that was from 2 up to 3,5 years of imprisonment showed that the objectives of sentencing was not maximal, moreover, the intervention programs was so conventional since it still referred to the so old Correctional Act of Law No. 12, 1995 that the benefit of the program could not be taken by the offender, the community, and the state. The intervention program managed by the correctional service, under the Correctional Act, was noble that the correctional system is managed to reform the inmates to become a whole man, introspecting, self-improving, and to not relapse committing their wrong doing for them to be accepted again in the community, to be actively play the role in the development of the state, and to be able to live well and full of responsibility. The above efforts is formulated in the Governmental Regulation on The Intervention Program of Inmates in the form of personality andindependency program. (Akhlak \& Korupsi, 2019).

The problem, however, is that if the program formulated in the regulation is imposed upon the offender of street crime, it is right on point even though it should be reviewed. On the contrary, if the program is designated to be applied upon the corruptor convict, it is deemed ineffective since the corruption offenders generally are officials or professionals and business actors who actually people with high level of intellectual, and even with quite-well knowledge of religion and in a healthy condition. Therefore, if the program under the Governmental Regulation is applied, the objectives of sentencing that is to reform the inmates to realize their fault, to self-improving, and to not commit the wrong doing again to be accepted in the community, to actively take part in the development and to be able to live a normal life as a good Samaritan and be responsible in doubtfully be achieved.

In such conditions, it can be said that the law has lost the ability to explain its relationship with society and cultural reality and finally the law can be said to have failed to become a medium that can increase public participation from various legal problems today, including the problem of fostering corruption convicts. (Susanto \& Batubara, 2016)

The sentencing includes an educational aspect. The sentencing is one form of legal education. In this legal education there is a transformation process of noble values. (Gialdah Tapiansari 
Batubara \& Arifin, 2019) The function of education is to develop abilities and shape the character and civilization of a dignified nation. So sentencing in which there are aspects of developing empathy and sense in doubtfully be achieved too. (Septiningsih, 2015) Based on the above problems, this article limits the problem to focus more on the discussion of what is the program effective for the community and the country based on the principle of local wisdom?

\section{Method}

This article is a report of research on the effectiveness of intervention program in the correctional service for corruption convict Class II A Sukamiskin which still refers to the Law No. 12, 1995 concerning Correctional Service with implementing regulation of Governmental Regulation No. 31, 1999. It is deemed necessary, based on facts found, to research on community service as the effort to reduce the burden of the state with the intervention progam for the inmates of corruption cases in Indonesia. This research is a legal research with juridical normative approach focusing on the legal norms as the main norms to make a new concept of law in the field of penology that is recommended to be included in the articles on criminal sanction or future Anti-corruption Act (ius constituendum) Based on the juridical normative approach, the stage of research was library research to find main data while field research done to find primary data as supporting data. The findings of primary and secondary data were processed by analyzing through juridical qualitative method concerning the legal assurance, legal objectives, the hierarchy of the law and the synchronization of law both vertical and horizontal. The qualitative research is descriptive research in that the researcher is interested in process, and meaning. And the process of qualitative research is inductive in that the researcher builds abstractons, concept and theories.

\section{Result And Discussion}

\section{A. The Correctional Program}

Correctional service is the end measures in criminal justice system that is expected to function as the institution to provide intervention program for inmates. Law No. 12, 1995 concerning Correctional Service is the legal basis for the program regardless the crime committed including crime of corruption. The program applied is an correctional program of personality and independency. The program consists of 3 (three) stages i.e., first, intervention during the first $1 / 3$ periode of incarceration is the early program in the form of admission and orientation. At this stage, the surveillance and monitoring done with maximum security method due to the transition condition of the inmates; treatment at the second $1 / 3$ period of incarceration that is the continuation and the treatment process of the personality (mental and spiritual) and independency begins. Normaly, at this stage, the inmate's data regarding level of education and interests and passion will be recorded. Also, at this stage, the monitoring is done with medium security. In addition, the assimilation process is also taken into account. The last, during the third $1 / 3$ period of their incarceration, the inmates will take the integration process or prisoner's release into the community. At this phase, inmates can be promoted to get a parole (PB), leave of absence prior to their prison release (CMB), and leave of absence with pre-requisites (CB).

The management of this treatment process is formulated in a governmental regulation as the implementing regulation of the law. Under the regulation, the treatment process is uniformly imposed upon all prisoners with no exception. However, if we consider the type of crime regardless the crime committed, the sanction imposed upon, and the discrepancy in kinds of sanction imposed upon, it is necessary to apply different program including different approach or method of treatment. Even though the program applied, one of which, is correction on personality necessary for all criminal convict, however, the process and approach/method used may be different. It is due to the characteristic, background (motive) of the action and the objectives of the sentencing imposed by the judges upon the corruptor convicts.

The corruptor convicts have different characteristic from convict of other crimes. The 
corruptor convicts were people posted as public officials as reported in Tribun Jabar's survey saying that during $2015-2019,105$ cases of corruption were committing by $r$ high ranking official of the region while KPK reported that from 2004 up to 2013, 569 cases had been investigated and 236 cases had been executed. The research of Transparency International Indonesia reported corruption index in 177 countries worldwide from December 2013 in which Indonesia ranked at 64 of the most corrupt countries in the world higher than other Asian countries. (Akhlak \& Korupsi, 2019). The corruptor convicts were people who sat at the strategic positions in either governmental institutions or private sectors. When we consider the verdict decided by the judge, the most severe judgment for corruption case was given in 2018 upon 3 cases. Those cases were 15 years of imprisonment against Setya Novanto, 15 years of incarceration against Irman and 15 years against Sugiharto. The lowest imprisonment imposed upon in 2018 was 2 years of incarceration against Donny Winoto; 2 years of imprisonment against Taufik Rahman and also 2 years of incarceration against Hasmun Hamzah (Kaleidoskop-2018-3-Vonis-Kasus-KorupsiPaling-Berat-Dan-Ringan-Tahun-Ini, n.d.) The correctional service is the last place for the inmates to be treated including the convict of corruption. Of the total 153,224 inmates incarcerated across Indonesia, about 2,936 are corruption convicts and 287 served their time at Sukamiskin Correctional.

The intervention process at the penitentiary is applied upon all inmates while in fact the length of time and kind of sanction imposed upon are various and will be correlated to the process of treatment and the objectives of the sentencing, especially if the inmates or offender are those who formally and materially competent so it is deemed ineffective if the criminal sanction imposed upon is imprisonment because their potency and compentence can no longer be useful for the community. In addition, the cost of the intervention program paid by the state is a lot especially the expenses for the inmates and for the treatment of the inmates. (Wardhani et al., 2016)

\section{B. Community Service as The Criminal Sanction}

There are many kinds of adat law in Indonesia that regulate the sanction of adat that is friendly to the offender, victims, and the community in which the sanction can give pretty great benefit for those three components: the offender, the community, and the country. The criminal sanction that can be adopted into the criminal law is community service that is a sanction that can optimize the skill or compentency held by the offender to be useful for the community while at the same time, the state can be at ease with the intervention program, the readiness of human resources and the expenses.Community service as a form of criminal sanction is an actualization of adat sanction aiming to not only to give deterrence effect but also to put back balance to the society or to the country after the corruption in addition to the utility principle as the basis in adat law. (Safrijal, 2013)

Philosophical basis of the community service as the sanction adopting the concept of adat sanction is the $5^{\text {th }}$ principle of Pancasila that is social justice for all the people of Indonesia meaning that every citizen of Indonesia should be treated fairly in the law, politics, social, economy, and culture. The benefit taken from the enforcement of community service through the internalization of the aim of sentencing through community service as the manifestation of the local wisdom should be truly felt by the community as the collateral damage of the corruption done by offender/officilas. At least the people who got the impact of the corruption or the people from where the the offender comes from. Therefore, it is expected to be a justice that serves the people and the state. The imposement of community service focuses on the upright of justice since philosophically, justice is the main element in achieving the aim of the law. Justice will reach out the ideal or be withing the idea and meaning.(Dwisvimiar, 2011) Threfore, when justice is served, other objectives of law, that is utility, will also be accomplished. Community service as the concept of this research is a supporting or complementary concept to the community service formulated in the Bill of Penal Code. It means that community service stated in the Bill of Penal Code is the 
one imposed upon misdemeanor with sanction is no more than 6 (six) months of incarceration or fine category I. However, in the enforcementof the community service, Article 88 of the Bill of Penal Code takes a lot into consideration used as the ground of the implementation of community service used as the concept of this research. However, the community service imposed upon the crime of corruption discussed in this research is not a substitute for the imprisonment as applied in some countries. Some countries have been applying the community service in their Criminal Code and other criminal act. This sanction generally is an alternative to shortterm incarceration or the substitute for the fine that the offender cannot afford, such as in Netherlands, Poland, Germany, United Kingdom, Portugal, Denmark and many other. In these countries, community service is successfully implemented.

In Netherland, Poland, and France, community service is stipulated as the main sanction. Indonesian Bill of Penal Code stipulates community service as one of the principal sanctions, therefore the main sanction stipulated in the Bill of Penal Code is the alternative to the short-term imprisonment not a non-custodial sanction or additional sanction since actually community service is a mild sanction.

\section{Community Service as a Main Sanction in Corruption}

Community service in corruption discussed in this research is a main sanction other than imprisonment. The application of community service for corruption should consider the local wisdom. Every region has its own district court of corruption and the convict are spread out in many correctional services. This means when implementing community service, it is necessary to consider the local wisdom of each region. Generally, corruption was committed by officials.

The concept offered are first, when the official committed corruption and he/she was born in, for example, West Java, the official should do the community service in West Java considering that the people where the official was born got their name defamed because the official was originally from that region. Second, if the offender of corruption stole some fund designated for the development of a region, for example, development fund of West Java, the official committing the corruption should do the community service in West Java considering the people of West Jave were the victims because the fund that had been stolen should have been used for the development in the region from where the people could get benefit. Third, if the corruptor convict stole the money designated for disaster relief in West Java, the convict should then do the work as same as the volunteer at the disaster area in which the fund should have been used for.

The convict should do community work during the disaster relief program in the disaster area. Fourth, if the convict stole the social security fund during the emergency period like what happened today when Indonesia fights the Covid-19 virus, the convict should do community service as same as what the volunteer do during the outbreak. This concept is believed to be able to give good psychological effect for the treatment of the convict of corruption. Impact according to Indonesian Grand Dictionary is a good influence, positive effect, or negative effect while psychology is viewed as mental aspect. Psychological impact related to the stimulus or response that can encourage people to act, therefore, psychological impact is consider as a result of process of stimulus and response that works inside a person. Psychological impact is also an experience therefore it can be said that psychological impact is related with action and effect. From above mention, it can be concluded that psychological impact is a positive and a negative influence resulted from stimulation and response that work inside oneself. The influence will be shown in the action and attitude of an individual. The psychological effect can affect directly or indirectly. From the concept above, to determine the type of community service to be imposed upon the convict, we should refer to the qualification of convict's educational background considering which differs one another. 
D. The Community Service is The Manifestation of Local Wisdom

Currently local wisdom regain its place. (Casram \& Dadah, 2019) Local wisdom is a cultural value and as a way of life that comes from the community so that local wisdom is believed to be true and becomes a reference in daily behavior. Local wisdom is the idea of the local community that is wise, full of wisdom, good value, which is embedded and followed by members of the community. (Hidayatuloh, 2019) The community service is the manifestation of local wisdom must be immediately regulated so that it can be used in corruption. Community service done by the convict aims to not only give a deterrence effect but also to restore balance in both society and the state because of the corruption committed by the convict. In addition, the community service is the manifestation of local wisdom since it should truly beneficial for the community as the collateral damage of the corruption. At least for the people who get the impact of the corruption or the people from where the convict is originated so that it is expected to be one of the justices that can be accessed by the people and the state.

In the concept above, the community service is to be done regularly by the convict during the time they should serve as the sanction or it is tentative not absolute because the length of the sanction is various. Therefore, it is also relative and is not absolute when it comes to determine whether the service is heavy or light. Still according to the concept of community service, the community service should be monitored because it is impossible for a person to do the work under no supervision. Supervision on the convict serving the community is done by the community. Community adjudicates and reports the what they consider good or bad attitude of the convict during the work.

This concept adopts and accommodates the local wisdom. Each region surely has special characteristic or uniqueness of their own wisdom. However, local wisdom does have universal principles some of which are harmony, amity, and balance that become the patterns of life of the community, the principle of tha harmony between man and the God, man and man, man and the environment and also principle of the comfortness and welfare both spiritually and physically. The concept above mentioned is the sentencing and treatment to realize the general principles of the local knowledge. The concept does not only adopt and accommodate the local wisdom but also adopts, accommodates, and tries to revive the characteristic of the eastern people in the eastern local wisdom.

Each region holds a specific characteristic of the people as their own wisdom. However, at least the in diversity of people characteristic, there is general one in each group of local wisdom i.e., the value of shame. The culture of shame is an attitude or pattern of behavior held and inherited in generations of a community of eastern. The culture of shame is eastern culture. Concept of community service for corruptor convict is a medium to remind, teach, and to revive the culture of shame to the offender or especially to corruptor convict and to people of Indonesia. We mentioned about reviving the culture of shame that concerns the criminal action committed in Indonesia mainly the crime of corruption committed by state officials. No wonder if the existence of culture of shame in Indonesia was questioned. The culture has never been wiped out. It still lives inside people and is actualized daily. Here, the culture or sense of shame will be used as the main criminal sanction through community service. The impact of the sanction given to corruptor convict is less effective. In addition, the sanction given to the corruptor convict did not make the convict felt ashamed of the crime committed.

Community service concept meets the element of correction and protect the community. The element of treatment in community service is oriented to the individual offender. Community service hinders the convict from negative impact such as stigmatization and self-esteem issue. The absence of stigmatization and the existence of self esteem are the important component in the intervention program. Community service gives chance to live the life normally. Freedom to live normally will give opportunity for the convict to remain usefull for their family. They can also be hindered from the 
process of dehumanization and therefore socializes in the society through community service. With this concept, the community service will trigger the shame in the convict The effort to make the convict feel ashamed and is expected to be deterred is actually has been done since the beginning of the trial process, followed up by the exposure by the media about the corruption committed. However, the efforts are yet to show that the corruptor is ashamed and deterred.

Therefore, it is deemed significant to continue the effort to make the corruptor feel ashamed and deterred through the imposement of community service. In eastern sociey (one of which is Indonesia), it cannot be denied that there is still stigma that corruptor deemed as failure to comply with the guiding norms and is failed to play their roles and duties (at least their professional duties). Failure to follow the norms and duties is shamefull. Culture of shame is relevant to be applied upon the corruption considering the act is an extraordinary crime (Extra Ordinary Crimes). The corruption phenomena show that it is systematic, vast, and atrocious for the nation. Corruption committed by officials dangerously affects the state integrity and national dignity. All components of nation including the people of Indonesia should bear the shame on the cases of corruption committed by the officials considering that level of corruption extremely influences the state rank. The corruption has smeared the state of Indonesia in the eye of international public. The nominal stolen by the officials reached more than trillion rupiahs. With that amount of money, be gone the state treasure. People suffer because their strategic rights politically, economically, socially, educationally, and culturaly are taken away. Corruption has humiliated human dignity and smeared the future of the nation and the state of Indonesia.

Corruption in Indonesia is not only occurred in politics but als in economy, social even in education and culture. It shows that the offender of various cases of corruption proven were committed by the countryman. It also shows that many stateman of politics, economy, social, education, and culture were sentenced for the crime. The victim of this corruption of politics, economy, social, education, and culture are the people of Indonesia as the stakeholders of the sovereignty in a democratice country. In corruption, the culprit official took opportunities and facilities in their power with all kinds of modus operandii to enrich themselves, others, and or corporation. Corruption through the offender will try to break the arrow of the truth to digression so that it affects the process of fair law enforcement to be unfair, consciously bias, and nonindependent.

The act of the corruption committed by the offender or what so called corruptor potential to affect the social climate in the society, in which the community do not respect the law and they are not committed to future development of the nation and better country so that one man will prey on another or in Latin is called Homo Homini Lupus meaning "Man is the wolf for other man". Corruption is an act of crime that can breed into another crime for example violation against human rights, crime against the freedom of media/press and others in the effort done by the corruptor to cover up their crime. The triumph in the fight against corruption will put the future of the nation at stake. Based on above considerations, the sentencing against the corruptor by sending them to do community service in the perspective of penal and non-penal enforcement is an appropriate, concrete, and autoritative solution to the eradication of corruption in the society.

Why is the culture of shame chosen to put forward and is adopted in the sanction of community service? It is believed that the culture of shame will play the important role in the shaping of one's personality. The culture of shame is a psychological reaction and it is believed that the culture will give a good psychological effect in the treatment of offender. The culture of shame as a culture is one of the important elements for the community life. It means that the culture of shame has a good social function for the treatment of offender when they are back into the society. From this culture of shame, a good moral and ethic will be born and then creates a harmonious interrelation between mans, 
politeness, and good utterance that in the end generates ta harmonious inter-group relation. Therefore, it is right that the culture of a country will certainly be affected by the characteristic of the countries' geography and the culture of a country affects mutually the characteristic of the people.

Local wisdom can be culture, customary, phenomenon, and tradition. In this context, local wisdom is local wisdom in the form of culture. Using the culture of shame as the eastern culture of Indonesian and the culture of shame as local knowledge of the society of Indonesia also as the basis principle of the used of community service as the treatment for the offender to be ashamed of what they have committed and it is expected that they are deterred. The basic principle as local knowledge is chosen as it is the national asset of culture that contains goodness for the life. The goodness in the local wisdom should be utilize including in the treatment of the inmates. The treatment for the convict should be done in the context of local wisdom. Local wisdom has potential social that can shape the character in the process of the treatment of the offender. Character formation is important because it will give a sense of responsibility. This responsibility will be reflected in the behavior of the convict. (Firdaus, 2020) This measure is the endeavor to preserve, adapt and develop the cultural heritage as well.

Culture must be preserved, (Wagiati \& Zein, 2018) adapted and developed. Preserving, adapting, and developing the culture is the duty of all Indonesians. Indonesian as the civilized country where various of culture exist in Indonesia need to be preserved. Each culture of Indonesia should be part of the responsibility of all to preserve. Preserving, adapting, and developing the cultural heritage is part of the concrete manifestation of the love for the culture of the nation and Indonesia. Not only to preserve, adapt, and develop the cultural heritage, to love the culture is also the responsibility of all as the citizen of Indonesia. Preserving, adapting, and developing the heritage of the culture is vital in the globalization era. This era unites the world and makes the world borderless and easy to communicate because technology is developing. Information is getting more easier to access; transportation is developing. Globalization has brought good flow however when we see in the view of local wisdom, globalization is threat to the local wisdom. Indonesia consists of vast territory with diversity of people. In its diversity, it certainly holds many specifications. Therefore, the local wisdom (in this case, the culture of shame) should be preserved for the meaning of the local wisdom will not gone. Leaving the Indonesian local wisdom will create the future of Indonesia uprooted from their characteristic of the country and the people of Indonesia. It should be understood that preserving the local wisdem in this modern era is very important.

Local wisdom is the root of nation inherited in the generations. Local wisdom should be guarded so that the legacy passed on will not be lost. Keeping the local wisdom can be done through some changes in parts that may need changes to face certain situation. These changes certainly done to keep the values of local wisdom. Local wisdom is a manifestation of the source of the nation's cultural norms and values. This form can be said to be a hidden principle or guide. (Effendi, 2015) Criminal law needs changes especially in the sentencing aspect of the corruptor convict in order to eradicate the crime of corruption and to give the deterrence effect. Imposing the criminal sanction in the form of community service is part of the effort to make changes in parts that need changing. Implementing community service is also a form of fostering corruption convicts who are oriented towards family law that is closer to the characteristics of Indonesia (Muslim and Customary Law Family), which displays Indonesian characteristics (moving from a collective order, based on local wisdom and reflecting the nation's political ideology), namely Pancasila. (Gialdah $\mathrm{T}$ Batubara \& Susanto, 2017) This is an important step in order to break the conventional sentensing model that does not provide the flexibility to appreciate the rights that exist in the criminal justice system in Indonesia today. (Yustia et al., 2015) This is a form of respect for humans too, because essentially the law is for humans as 
well as guidance for humans (corruption convicts).

\section{CONCLUSION}

The concept of community service is the concept as the additional sanction or as the principal sanction in some sorts in addition to incarceration stipulating in the Anti-Corruption Act. The concept of community service is a reflection of customary law of as the part of local wisdom based on Pancasila, especially the fifth Sila in addition to the utility as the basis of adat law. Community service as the criminal sanction is an actualization of adat sanction aiming not only to give deterrence effect but also to balance the condition that has been destroyed in the community or in the country due to the corruption. The concept of community service in its application always designated for its utility and the principle of justice for the offender, society, and the country.

The appropriate treatment that can make the offender useful for the community and the country based on the principles of local wisdom is the treatment through community service. By applying the community service 3 (three) stages of treatment i.e., first $1 / 3$ period of incarceration, second $1 / 3$ period of incarceration, and the third $1 / 3$ period of incarceration remains applied but the program is directly in the community by considering the principles of local wisdom where the convict serves their time of sanction. Community service is criminal sanction that is able to meet the purpose of sentencing that is the protection of the community and rehabilitation of the offender. Therefore, it is relevant to say that community service fit or in line with the purpose of sentencing.

So many positive sides or advantages from the imposement of sanction of community service therefore it is necessary for the legislatives to immediately formulate the sanction in the AntiCorruption Act and in the Bill of Penal Code as the principal criminal sanction equal with the imprisonment. Because community service in corruption discussed in this research is a main sanction other than imprisonment. The application of community service for corruption should consider the local wisdom. Every region has its own district court of corruption and the convict are spread out in many correctional services. This means when implementing community service, it is necessary to consider the local wisdom of each region.

Concept of community service for corruptor convict is a medium to remind, teach, and to revive the culture of shame to the offender or especially to corruptor convict and to people of Indonesia. We mentioned about reviving the culture of shame that concerns the criminal action committed in Indonesia mainly the crime of corruption committed by state officials and generally, corruption was committed by officials. No wonder if the existence of culture of shame in Indonesia was questioned. The culture has never been wiped out. It still lives inside people and is actualized daily. Here, the culture or sense of shame will be used as the main criminal sanction through community service. The impact of the sanction given to corruptor convict is less effective. In addition, the sanction given to the corruptor convict did not make the convict felt ashamed of the crime committed.

\section{References}

Akhlak, K., \& Korupsi, N. (2019). Q UANTA. $3(1), 1-5$. https://doi.org/10.22460/q.v1i1p110.497

Batubara, Gialdah T, \& Susanto, A. F. (2017). Pola Penegakan Hukum Pidana Berdasarkan Nilai-Nilai Kemanusiaan Dalam Perspektif Asas Manfaat. Jurnal Litigasi, 18(1), 41-86. https://journal.unpas.ac.id/index.php/liti gasi/article/view/287/521

Batubara, Gialdah Tapiansari, \& Arifin, F. (2019). Model Pendidikan Hukum Dalam Upaya Mewujudkan Kesadaran Hukum Siswa Sejak Dini. Litigasi, 20(1), 20-56. https://doi.org/10.23969/litigasi.v20i1.21 06

Casram, C., \& Dadah, D. (2019). Posisi Kearifan Lokal Dalam Pemahaman 
Keagamaan Islam Pluralis. Jurnal Studi Agama-Agama Dan Lintas Budaya, 3(2), 161-187.

https://journal.uinsgd.ac.id/index.php/Re ligious/article/view/4739/pdf

Dwisvimiar, I. (2011). Keadilan Dalam Perspektif Filsafat Ilmu Hukum. Jurnal Dinamika Hukum, 11(3), 522-531. https://doi.org/10.20884/1.jdh.2011.11.3. 179

Effendi, N. (2015). Kearifan Lokal Menuju Penguatan Karakter Sosial: Suatu Tantangan Dari Kemajemukan Budaya Di Sumatera Barat. Jurnal Antropologi: Isu-Isu Sosial Budaya, 16(2), 107-115. http://jurnalantropologi.fisip.unand.ac.id /index.php/jantro/article/view/27

Firdaus, R. G. (2020). Pembelajaran Cinta Lingkungan Berdasarkan Pembentukan Karakter dan Penerapan Konsep 3R.

Journal Simposium Nasional Mulitidisiplin, 2.

http://jurnal.umt.ac.id/index.php/senamu /article/view/3489/2380

Hidayatuloh, S. (2019). Nilai-Nilai Kearifan Lokal Upacara Adat Ngikis Di Situs Karangkamulyan Kabupaten Ciamis. Patanjala: Jurnal Penelitian Sejarah Dan Budaya, 11(1 Maret), 97-113. https://www.neliti.com/publications/291 830/nilai-nilai-kearifan-lokal-upacaraadat-ngikis-di-situs-karangkamulyankabupaten

kaleidoskop-2018-3-vonis-kasus-korupsipaling-berat-dan-ringan-tahun-ini. (n.d.).

Safrijal, A. (2013). Penerapan Sanksi Adat dalam Penyelesaian Perkara Pidana di Kabupaten Nagan Raya. Kanun Jurnal Ilmu Hukum, 15(1), 145-162. https://doi.org/10.24815/kanun.v15i1.61 65

Septiningsih, L. (2015). Membangun Karakter Bangsa Berbasis Sastra: Kajian Terhadap Materi Karya Sastra Di Sekolah Menengah Atas. Jurnal Pendidikan Dan Kebudayaan, 21(1), 71-85.

https://jurnaldikbud.kemdikbud.go.id/ind ex.php/jpnk/article/view/177/159

Susanto, A. F., \& Batubara, G. T. (2016).
Partisipatoris: Sebuah Gagasan Dan

Konsep Awal. Jurnal Litigasi, 17(2), 3314-3376.

https://doi.org/http://dx.doi.org/10.23969 /litigasi.v17i2.159

Wagiati, W., \& Zein, D. (2018). Pemertahanan Bahasa Sunda Dalam Upacara Pernikahan Tradisional Di Kabupaten Bandung. Jurnal Pendidikan Dan Kebudayaan, 3(2), 186-201. https://jurnaldikbud.kemdikbud.go.id/ind ex.php/jpnk/article/view/1031

Wardhani, N. S., Hartati, S., \& Rahmasari, H. (2016). Sistem Pembinaan Luar Lembaga Bagi Narapidana Yang Merata Dan Berkeadilan Berperspektif Pada Tujuan Pemasyarakatan. Jurnal Hukum \& Pembangunan, 45(1), 1. https://doi.org/10.21143/jhp.vol45.no1.7 Yustia, D. A., Rastuti, T., \& Fatimah, U. D. (2015). Mendobrak Kelemahan Litigasi Konvensional Melalui Model Advokasi Mandiri Dalam Rangka Pembaharuan Proses Peradilan. Jurnal Litigasi, 16, No. 1(April). https://doi.org/http://dx.doi.org/10.23969 /litigasi.v16i1.51 